Pawee BlajeR ${ }^{1}$

\title{
Definicja i status rolnika indywidualnego w świetle nowelizacji ustawy o kształtowaniu ustroju rolnego
}

\section{Uwagi wstępne}

Wśród wielu nowości legislacyjnych, jakie przyniosło ze sobą wejście w życie ustawy z dnia 16 września 2011 roku o zmianie ustawy o gospodarowaniu nieruchomościami rolnymi Skarbu Państwa oraz o zmianie niektórych innych ustaw, ${ }^{2}$ na szczególną uwagę zasługuje modyfikacja regulacji zawartych w ustawie $\mathrm{z}$ dnia 11 kwietnia 2003 roku o kształtowaniu ustroju rolnego. ${ }^{3}$ Zmiany dotyczą między innymi fundamentalnej dla polskiego prawa rolnego instytucji gospodarstwa rodzinnego, stanowiącej - zgodnie z art. 23 Konstytucji RP - podstawę ustroju rolnego państwa. Mocą art. 3 pkt 4 ustawy z 16 września 2011 roku znowelizowany został bowiem przepis art. 6 u.k.u.r. zawierający definicję rolnika indywidualnego. W konsekwencji, z uwagi na fakt, że definicja ta stanowi podstawowy element konstrukcyjny definicji gospodarstwa rodzinnego, także to ostatnie, konstytucyjne pojęcie uległo poważnej modyfikacji.

Powyższa okoliczność skłania do dokładniejszego przeanalizowania najnowszych zmian w zakresie definicji rolnika indywidualnego w u.k.u.r. Do podjęcia rozważań w tym temacie zachęca również fakt, że poprzednia definicja rolnika indywidualnego spotykała się ze szczególnie ostrą i dobrze uzasadnioną krytyką w literaturze agrarystycznej. ${ }^{4}$ Jak się wydaje, słabych stron tej definicji świadom był zresztą sam ustawodawca, podejmując próby jej modyfikacji już w toku prac Sejmu VI kadencji (lata 2005-2007). ${ }^{5}$ Plany te udało się jednak urzeczywistnić dopie-

\footnotetext{
Uniwersytet Jagielloński.

Dz.U. z 2011 r. Nr 233, poz. 1382. Ustawa weszła w życie w dniu 3 grudnia 2011 roku.

Tekst jedn. Dz.U. z 2012 r. poz. 803 - dalej zwana „u.k.u.r.”

Por. A. Lichorowicz, Instrumenty oddziaływania na strukturę gruntową Polski w ustawie z 11 kwietnia 2003 r. o kształtowaniu ustroju rolnego, „Kwartalnik Prawa Prywatnego” 2004, z. 2, s. 393 i n.; A. Majewski, Problematyka kwalifikacji do prowadzenia działalności rolniczej w gospodarstwach rolnych, „Studia luridica Agraria” 2005 , t. 5, s. 185 i n.; P. Blajer, Pojęcie rolnika indywidualnego w ustawie o kształtowaniu ustroju rolnego, „Studia luridica Agraria" 2007, t. 6, s. 180 i n. idem, Koncepcja prawna rolnika indywidualnego w prawie polskim na tle porównawczym, Kraków 2009, s. 347 i n.; idem, Wymóg kwalifikacji rolniczych w obrocie nieruchomościami rolnymi (studium prawno-porównawcze), „Przegląd Prawa Rolnego” 2008, nr 2, s. 51 i n.
} 
ro na finiszu prac Sejmu kolejnej kadencji, choć podkreślić należy, że treść noweli z 2011 roku nie odbiega w znaczący sposób od propozycji zgłaszanych już w roku 2007.

Celem niniejszego opracowania jest zatem podjęcie próby odpowiedzi na pytanie, na ile nowa redakcja definicji rolnika indywidualnego wychodzi naprzód licznym postulatom zgłaszanym $\mathrm{w}$ tym względzie $\mathrm{w}$ doktrynie, a tym samym, na ile stanowi ona krok naprzód w porównaniu do poprzedniego, nieudanego sposobu ujęcia tej instytucji w u.k.u.r. Praca niniejsza zmierza ponadto do wskazania aktualnego statusu rolników indywidualnych po zmianach wprowadzonych ustawą z 16 września 2011 roku. Założone w przedmiotowym opracowaniu cele badawcze wyznaczają także jego konstrukcję, toteż w pierwszej kolejności omówione zostaną najnowsze zmiany redakcyjne w zakresie definicji rolnika indywidualnego oraz dokonana zostanie ich ocena. Dalsza część pracy poświęcona będzie ostatnim modyfikacjom statusu rolnika indywidualnego. W ramach uwag końcowych sformułowane zostaną ogólniejsze wnioski zarówno co do aktualnego stanu prawnego, jak i ewentualnych dalszych kierunków zmian.

\section{Nowe ujęcie kryteriów konstruujących definicję rolnika indywidualnego}

W uzasadnieniu poselskiego projektu ustawy o zmianie ustawy o gospodarowaniu nieruchomościami rolnymi Skarbu Państwa ${ }^{6}$ jego autorzy wskazują, iż zmiany w zakresie definicji rolnika indywidualnego miały na celu ,uszczegółowienie kryteriów uznania osoby fizycznej za rolnika indywidualnego", gdyż warunki określone w poprzednio obowiązującej ustawie były zbyt „ogólne”. W konsekwencji uchwalona w dniu 16 września 2011 roku ustawa zmodyfikowała wszystkie cztery kryteria składające się na definicję rolnika indywidualnego. Warto w tym miejscu uważniej przeanalizować wprowadzone zmiany.

2.1. W zakresie tzw. kryterium „obszarowego" " nowości wprowadzone ustawą z dnia 16 września 2011 roku nie mają charakteru fundamentalnego. Uściślono mianowicie, iż za rolnika indywidualnego uważa się nie tylko osobę fizyczną będącą właścicielem lub dzierżawcą nieruchomości rolnych o łącznej powierzchni użytków rolnych nieprzekraczającej 300 hektarów - tak jak to miało miejsce na gruncie u.k.u.r. w jej pierwotnym brzmieniu. Sumowaniu do wspomnianej normy obszarowej podlegają bowiem aktualnie również nieruchomości rolne, którymi dana osoba włada jako użytkownik wieczysty lub też bez tytułu prawnego - jako ich samoistny posiadacz. 
Przedmiotową zmianę kryterium obszarowego należy uznać za generalnie uzasadnioną. Trudno wskazać racjonalne powody, dlaczego w poprzednim stanie prawnym uwzględnieniu przy obliczaniu normy obszarowej podlegały wyłącznie użytki rolne stanowiące własność lub przedmiot dzierżawy danej osoby fizycznej. Aktualnie również osoba będąca użytkownikiem wieczystym lub tylko samoistnym posiadaczem takich gruntów musi uwzględniać je przy obliczaniu maksymalnej normy obszarowej 300 ha użytków rolnych, po której przekroczeniu traci status rolnika indywidualnego i związane z nim przywileje. W tym zatem względzie kryterium obszarowe uległo zaostrzeniu, eliminując z zakresu pojęcia „rolnik indywidualny” np. osoby będące użytkownikami wieczystymi rozległych areałów państwowych gruntów rolnych. ${ }^{8}$ Pojawia się jednak pytanie, dlaczego przy redakcji tego kryterium nie uwzględniono także innych potencjalnych tytułów prawnych do nieruchomości rolnych, w szczególności licznych przypadków posiadania zależnego takich nieruchomości - np. na podstawie umów użytkowania lub użyczenia. Ustawodawca mógł uznać, że takie przypadki należą w praktyce do rzadkości, niemniej pozostawił tym samym uchyloną furtkę dla prób obchodzenia w przyszłości 300-hektarowej normy obszarowej, którą uznał na tyle istotną, iż zdecydował się ją w dalszym ciągu utrzymać jako jedno z kryteriów konstruujących definicję rolnika indywidualnego.

Należy jednak jeszcze raz podnieść wątpliwości co do sensu utrzymywania tego kryterium w przyszłości. ${ }^{9}$ Zwracano już uwagę w piśmiennictwie, że tego typu ściśle określone normy obszarowe należą - jako anachroniczne - do rzadkości w prawnorolnych regulacjach obowiązujących w państwach Europy Zachodniej, gdzie zastępowane są przede wszystkim przez rozmaicie konstruowane kryteria dochodowości. ${ }^{10}$ Sposób redakcji przedmiotowego kryterium w u.k.u.r. pozwala ponadto podtrzymać zarzut arbitralności przyjętych rozwiązań. Wypada zadać pytanie o przesłanki, jakie kierowały ustawodawcą, gdy określał wspomnianą normę obszarową na pułapie 300 ha użytków rolnych. W konsekwencji, w zakresie definicji rolnika indywidualnego w dalszym ciągu umieszcza się rolników o bardzo zróżnicowanym statusie - tzn. zarówno drobnych gospodarzy dysponujących 1 ha użytków rolnych, jak i osoby, których gospodarstwa liczą aż 300 ha.

Warto w tym miejscu podnieść, że uwzględnienie wśród gruntów podlegających sumowaniu do normy 300 ha także nieruchomości znajdujących się w użytkowaniu wieczystym danej osoby, nie oznacza wcale, iż regulacją innych przepisów u.k.u.r. - w szczególności art. 3 i 4 tej ustawy - objęty został obrót prawem użytkowania wieczystego nieruchomości rolnych. W związku z tym za wciąż aktualny należy uznać pogląd Z. Truszkiewicza, zgodnie z którym u.k.u.r. „nie ma zastosowania do przenoszenia użytkowania wieczystego nieruchomości rolnej lub do oddawania takiej nieruchomości w użytkowanie wieczyste". Por. Z. Truszkiewicz, Przeniesienie własności nieruchomości rolnej w świetle ustawy o kształtowaniu ustroju rolnego (część I), „Rejent” 2003, nr 9, s. 52. Prawo użytkowania wieczystego gruntów rolnych wraz z prawem własności, dzierżawą oraz samoistnym posiadaniem jest jednym $z$ wielu elementów konstruujących aktualnie definicję rolnika indywidualnego oraz gospodarstwa rodzinnego, nie zostało natomiast objęte innymi szczegółowymi regulacjami u.k.u.r., takimi jak prawo pierwokupu dzierżawcy (art. 3 ust. 1 u.k.u.r.), prawo pierwokupu Agencji Nieruchomości Rolnych (art. 3 ust. 4 u.k.u.r.) czy wreszcie tzw. prawo nabycia przysługujące tej Agencji (art. 4 u.k.u.r.). 
Nowelizacja u.k.u.r. nie przyniosła również zmian odnośnie do dowodów potwierdzających spełnianie przez zainteresowanego przedmiotowego kryterium. Nadal jedyny dowód stanowi oświadczenie potencjalnego rolnika indywidualnego składane w akcie notarialnym obejmującym umowę prowadzącą do przeniesienia własności nieruchomości rolnej w celu powiększenia gospodarstwa rodzinnego (art. 3 ust. 7 oraz art. 4 ust. 4 pkt 1 u.k.u.r.) lub oświadczenie o skorzystaniu z prawa pierwokupu takiej nieruchomości przysługującego mu jako jej dzierżawcy (art. 3 ust. 1 u.k.u.r.) Stosownie do przepisu art. 7 ust. 6 u.k.u.r. w oświadczeniu tym należy podać łączną powierzchnię i miejsce położenia nieruchomości rolnych, których nabywca jest właścicielem, użytkownikiem wieczystym, dzierżawcą lub samoistnym posiadaczem. Oświadczenie to nadal nie wymaga żadnego urzędowego poświadczenia dokonywanego przez wójta. Uregulowanie takie może budzić uzasadnione wątpliwości z uwagi na fakt, iż od prawdziwości oświadczenia zależy ważność dokonywanej czynności prawnej. ${ }^{11}$

2.2. Formalnie niewielkie zmiany redakcyjne poczynione zostały również $\mathrm{w}$ zakresie tzw. kryterium ,zamieszkania”. Wprowadzono bowiem wymóg by rolnik zamieszkiwał co najmniej od pięciu lat w gminie, na obszarze której jest położona jedna z nieruchomości rolnych wchodzących w skład gospodarstwa rolnego. Dowodem potwierdzającym spełnienie tego kryterium począwszy od 1 stycznia 2013 będzie zaświadczenie o zameldowaniu na pobyt stały wydawane na podstawie art. 32 ustawy z dnia 24 września 2010 roku o ewidencji ludności. ${ }^{12}$ Obowiązek uzyskania takiego zaświadczenia na potrzeby u.k.u.r. będą mieli nie tylko obywatele Rzeczypospolitej Polskiej, ale również cudzoziemcy - stosownie do art. 40 wyżej powołanej ustawy o ewidencji ludności. Kwestia dowodów potwierdzających spełnienie przedmiotowego kryterium począwszy od 2013 roku ulega zatem daleko idącemu uproszczeniu - w szczególności w porównaniu $\mathrm{z}$ aktualnie obowiązującym wymogiem przedłożenia dokumentu określającego zameldowanie na pobyt stały w rozumieniu przepisów o ewidencji ludności i dowodach osobistych, różnicujących dokumenty potwierdzające fakt zameldowania na pobyt stały w zależności od obywatelstwa danej osoby. ${ }^{13}$

W uzasadnieniu projektu ustawy nowelizującej u.k.u.r. wskazano, iż wprowadzenie minimalnego okresu zamieszkania na terenie gminy, w której znajduje się

Należy bowiem wskazać, że nawet niezawiniona omyłka w oświadczeniu, w sytuacji gdy składający je jest w rzeczywistości właścicielem, dzierżawcą, użytkownikiem wieczystym lub samoistnym posiadaczem użytków rolnych o powierzchni przekraczającej 300 ha powoduje, że stroną czynności przestają być rolnik indywidualny w rozumieniu u.k.u.r., a zatem np. umowa sprzedaży nieruchomości rolnej zawierana przez taką osobę formalnie w celu powiększenia gospodarstwa rodzinnego dotknięta jest sankcją bezwzględnej nieważności jako nieuwzględniająca pierwokupu Agencji Nieruchomości Rolnych. Warto odnotować, że ostatnie rozszerzenie zakresu kryterium obszarowego także na grunty będące przedmiotem posiadania samoistnego rolnika sprawia, że o tego typu pomyłki może być aktualnie łatwiej niż w przeszłości. 
gospodarstwo, uzasadnione jest koniecznością zapobiegania sytuacjom, w których grunty rolne nabywane były przez przedsiębiorcze osoby niebędące rolnikami, chociażby dla otrzymywania dopłat lub $\mathrm{w}$ celach spekulacyjnych. ${ }^{14} \mathrm{~W}$ poprzednio obowiązującym stanie prawnym zameldowanie się $\mathrm{w}$ miejscowości położenia nieruchomości chociażby na jeden dzień przed dniem zawarcia umowy prowadzącej do jej nabycia lub przed dniem przeprowadzenia przetargu na jej sprzedaż powodowało spełnienie wymogu zamieszkiwania w gminie, na obszarze której jest położona jedna $\mathrm{z}$ nieruchomości wchodzących w skład gospodarstwa rodzinnego. W konsekwencji, przy spełnieniu pozostałych kryteriów, okoliczność ta pociągała za sobą uzyskanie statusu rolnika indywidualnego i związanych z tym statusem przywilejów przewidzianych w u.k.u.r. i w ustawie z dnia 19 października 1991 roku o gospodarowaniu nieruchomościami rolnymi Skarbu Państwa. ${ }^{15}$

W kontekście poprzedniej regulacji, dopuszczającej opisane nadużycia, zmiany w zakresie kryterium zamieszkania należy uznać za racjonalne i uzasadnione. Niemniej wprowadzenie wymogu długiego, 5-letniego okresu zamieszkania w gminie, na obszarze której położona jest jedna z nieruchomości wchodzących w skład gospodarstwa rolnego, zdaje się uzasadniać podejrzenia A. Lichorowicza, który w zastosowaniu kryterium zamieszkania jako elementu konstruującego definicję rolnika indywidualnego widział przede wszystkim przeszkodę dla uzyskiwania tego statusu przez cudzoziemców - w szczególności obywateli państw członkowskich Unii Europejskiej - a tym samym instrument ochrony polskich gruntów rolnych przed wykupem z ich strony. ${ }^{16}$ Być może zatem, iż - w perspektywie zbliżającego się roku 2016 i końca okresu przejściowego, po którym obywatele państw - stron umowy o Europejskim Obszarze Gospodarczym albo Konfederacji Szwajcarskiej będą nabywali nieruchomości rolne i leśne położone na terytorium RP bez konieczności uzyskania zezwolenia Ministra Spraw Wewnętrznych - przedmiotowe kryterium zamieszkania w jego nowej redakcji stanie się skuteczną przeszkodą dla uzyskiwania przez nich statusu rolnika indywidualnego i tym samym nabywania przez nich gruntów rolnych na formalnie preferencyjnych zasadach zastrzeżonych dla tej kategorii rolników. ${ }^{17}$

2.3. Znacznie istotniejsze zmiany ustawa nowelizująca wprowadziła w zakresie kryterium „osobistego prowadzenia gospodarstwa”. Zgodnie bowiem z przepisem art. 6 ust. 2 w nowym brzmieniu uważa się, że osoba fizyczna osobiście prowadzi gospodarstwo rolne, jeżeli a) pracuje w tym gospodarstwie, b) podejmuje wszelkie

Warto zwrócić uwagę, że pierwotnie planowano wprowadzenie jedynie 3-letniego termin zamieszkania w gminie, w której znajduje się gospodarstwo, jako przesłanki uzyskania statusu rolnika indywidualnego. W ostatecznie uchwalonym tekście ustawy zdecydowano się jednak przedłużyć ten termin do 5 lat. Dz.U. z 2007 r. Nr 231, poz. 1700, z późn. zm.

16 Por. A. Lichorowicz, Instrumenty oddziaływania na strukturę gruntową Polski..., op. cit., s. 402.

17 Por. art. 8 ust. 2 ustawy z dnia 24 marca 1920 r.oku o nabywaniu nieruchomości przez cudzoziemców (tekst jedn. Dz.U. z 2004 r. Nr 167, poz. 1758). 
decyzje dotyczące prowadzenia działalności rolniczej w tym gospodarstwie. Wymóg osobistego prowadzenia gospodarstwa uległ zatem doprecyzowaniu poprzez wskazanie, iż rolnik indywidualny nie powinien ograniczać się wyłącznie do podejmowania wszelkich decyzji dotyczących funkcjonowania gospodarstwa, ale powinien w nim także pracować.

Warto zwrócić uwagę, że przytoczona modyfikacja kryterium osobistego prowadzenia gospodarstwa stała się przedmiotem szczególnie szerokiego omówienia w uzasadnieniu projektu ustawy. Autorzy projektu zwracają w nim uwagę, że o osobistym prowadzeniu gospodarstwa nie świadczy wyłącznie podejmowanie wszelkich decyzji dotyczących funkcjonowania gospodarstwa, w tym zawieranie umów $\mathrm{z}$ dostawcami, odbiorcami, bankami i ubezpieczycielami, ale również praca $\mathrm{w}$ tym gospodarstwie rolnym. Z powołaniem się na orzecznictwo Sądu Najwyższego autorzy projektu dowodzą, iż jedną z najistotniejszych przesłanek świadczących o osobistym prowadzeniu gospodarstwa rolnego jest praca w tym gospodarstwie w wymiarze i z częstotliwością odpowiednią do charakteru prowadzonej produkcji, a utrata zdolności do pracy w gospodarstwie rolnym oznacza utratę możliwości jego prowadzenia. W konsekwencji dochodzą do wniosku, że gospodarstwo rodzinne, będące kwalifikowanym typem gospodarstwa rodzinnego, opiera się na pracy prowadzącego je rolnika, a zatem wymogu pracy w gospodarstwie rolnym nie można pominąć przy konstruowaniu definicji rolnika indywidualnego.

Wyżej przytoczone argumenty zasługują na bliższą analizę. Rzeczywiście w literaturze agrarystycznej podnoszono, że poprzedni sposób sformułowania kryterium osobistego prowadzenia gospodarstwa, koncentrujący się tylko na okoliczności podejmowania przez rolnika wszelkich decyzji dotyczących prowadzenia działalności rolniczej w gospodarstwie, budził daleko posunięte wątpliwości. Zwracano uwagę, że taka redakcja omawianego kryterium pozwalała objąć definicją rolnika indywidualnego także osoby nie świadczące osobistej pracy w gospodarstwie rodzinnym, a podejmujące tylko decyzje dotyczące prowadzonej w nim działalności rolniczej i komunikujące je wykonawcom, np. za pośrednictwem środków bezpośredniego porozumiewania się na odległość. ${ }^{18}$ Takim niezamierzonym efektom poprzedniej regulacji miało właśnie zapobiegać wprowadzenie obowiązku pracy w gospodarstwie jako elementu konstruującego przesłankę osobistego prowadzenia gospodarstwa.

Niemniej należy zauważyć, iż nowa regulacja także nie rozwiewa wszelkich wątpliwości, przede wszystkim zresztą z uwagi na nieprecyzyjność użytych w niej określeń i niejasność obowiązku pracy w gospodarstwie rolnym. Ustawodawca nie uściślił bowiem, w jakim charakterze rolnik powinien świadczyć tę pracę w swoim gospodarstwie. Czy pod pojęciem pracy w gospodarstwie należy rozumieć stałą ak- 
tywność rolnika bezpośrednio przy produkcji rolnej, ograniczoną do pracy fizycznej związanej bezpośrednio z wytwarzaniem określonych produktów, czy też dla spełnienia tego wymogu wystarczy praca w gospodarstwie świadczona tylko sporadycznie, sezonowo albo ograniczona wyłącznie do czynności administracyjno-kierowniczych? Te ostatnie również stanowią formę pracy, która może być wykonywana $\mathrm{w}$ gospodarstwie rolnym. Czy wreszcie praca rolnika indywidualnego w gospodarstwie zakłada, że nie powinien on podejmować zatrudnienia gdzie indziej, czy też wprost przeciwnie - nie jest on w jakimkolwiek stopniu skrępowany w możliwości świadczenia pracy poza rolnictwem? ${ }^{19}$ Należy wyrazić żal, że odwołując się do wymogu pracy, a więc kryterium podmiotowego o długiej tradycji w polskich regulacjach prawnorolnych, ${ }^{20}$ ustawodawca określił je tak lakonicznie, nie korzystając $\mathrm{w}$ tym zakresie $\mathrm{z}$ bogatego dorobku orzecznictwa i doktryny, podsuwających gotowe wzory bardziej precyzyjnej regulacji. ${ }^{21}$

Odnośnie do nowej redakcji kryterium osobistego prowadzenia gospodarstwa rodzinnego można sformułować jeszcze kilka bardziej teoretycznych uwag. Należy zwrócić uwagę na aprioryczne założenie ustawodawcy, utożsamiającego prowadzenie gospodarstwa $\mathrm{z}$ pracą $\mathrm{w}$ takiej jednostce produkcyjnej. Tymczasem nie można zapominać, że w ustawodawstwach zachodnioeuropejskich te dwa kryteria - pracy w gospodarstwie oraz osobistego jego prowadzenia - są niejednokrotnie ostro sobie przeciwstawiane i traktowane jako dwa zupełnie odrębne i niezależne wymogi podmiotowe. Tego typu punkt widzenia jest charakterystyczny np. dla szwajcarskich i francuskich regulacji prawnorolnych..$^{22}$ Natomiast na płaszczyźnie polskich unormowań wykorzystujących przedmiotowe kryterium, a także w świetle wypowiedzi doktryny i orzecznictwa, przedmiotowy problem nie doczekał się jak dotąd jednoznacznego rozstrzygnięcia. W niektórych wypadkach wymóg „osobistego prowadzenia gospodarstwa rolnego" ograniczany był wyłącznie do sprawowania funkcji kierowniczych lub zarządczych, bez konieczności świadczenia własnoręcznej pracy przy produkcji rolnej. ${ }^{23}$ Innym razem wszelako podkreślano, że „kierowanie i zarzą-

Jak się wydaje, brak wyraźnego rozstrzygnięcia tej kwestii przez ustawodawcę zdaje się przemawiać za wnioskiem, że nic nie stoi na przeszkodzie, aby rolnik indywidualny mający formalny obowiązek pracy w gospodarstwie rodzinnym, świadczył tam pracę w wymiarze minimalnym, większość swoich dochodów czerpiąc z działalności o zupełnie odmiennym charakterze (np. szeroko pojętej działalności gospodarczej) i tej właśnie pozarolniczej działalności poświęcając przeważającą część swojego czasu pracy. Jednak należy zastrzec, że jest to jeden z kilku możliwych kierunków interpretacji.

20 Por. np. dawny art. 1059 kc. - w szczególności w wersji ustalonej ustawą z dnia 26 marca 1982 roku o zmianie ustawy - Kodeks cywilny (Dz.U. z 1982 r. Nr 11, poz. 81), który jako jedną z przesłanek warunkujących możliwość odziedziczenia gospodarstwa rolnego wymieniał „stałą pracę w gospodarstwie rolnym bezpośrednio przy produkcji rolnej".

21 Więcej na temat ujęcia kryterium pracy w regulacjach prawnorolnych w Polsce: P. Blajer, Koncepcja prawna..., op. cit., s. 259. Por. w szczególności powołaną tam obszerną literaturę i orzecznictwo.

22 Por. Blajer, Koncepcja prawna..., op. cit., s. 87.

23 Por. w szczególności przepis § 6 pkt 1 instrukcji nr 3 Ministra Rolnictwa z dnia 23 marca 1972 roku definiujący pojęcie „rolnika” z art. 1 ust. 1 ustawy z dnia 26 października 1971 roku o uregulowaniu własności gospodarstw rolnych (Dz.U. Nr 27, poz. 250), zgodnie z którym „rolnikiem w rozumieniu ustawy jest samoistny posiadacz nieruchomości, gospodarujący na niej osobiście lub przy pomocy pozostających z nim we wspólności domowej członków rodziny", co zgodnie interpretowano jako odwołanie do kryterium osobistego prowadzenia gospodar- 
dzanie gospodarstwem wiąże się z osobistymi staraniami o jego należyte funkcjonowanie oraz stałym, osobistym wykonywaniem niezbędnych prac". ${ }^{24} \mathrm{~W}$ związku z powyższym, nie można podzielić zdania autorów projektu noweli, że za niekwestionowany należy uznać pogląd o pracy w gospodarstwie rolnym, jako najistotniejszej przesłance świadczącej o osobistym prowadzeniu gospodarstwa. Zakresy kryteriów pracy oraz osobistego prowadzenia gospodarstwa rolnego na płaszczyźnie polskich regulacji nigdy nie były bowiem dostatecznie wyraźnie oddzielone, a aktualne unormowanie należy uważać raczej tylko za przejaw określonej tendencji, nie zaś za ostateczne i generalne rozstrzygnięcie analizowanego problemu.

Nowelizacja nie zlikwidowała również kolejnej usterki w poprzedniej redakcji kryterium osobistego prowadzenia gospodarstwa, o której zresztą szeroko pisano $\mathrm{w}$ literaturze. ${ }^{25} \mathrm{~W}$ dalszym ciągu, by spełnić przedmiotowy wymóg rolnik indywidualny powinien podejmować ,wszelkie” decyzji dotyczące prowadzenia działalności rolniczej w swoim gospodarstwie. W konsekwencji utrzymana została w ramach definicji rolnika indywidualnego dotychczasowa semantyczna niezręczność formalnie wykluczająca w obrębie gospodarstwa rodzinnego jakikolwiek podział pracy i zadań, charakterystyczny przecież dla gospodarstwa prowadzonego przez rodzinę rolniczą. Pomimo faktu, iż z tym problemem poradzono sobie w doktrynie ${ }^{26}$

stwa rolnego. Zdaniem J. Paliwody (Problemy prawne uregulowania własności gospodarstw rolnych, Wrocław 1976, s. 31) podstawowe znaczenie dla oceny czy dany rolnik rzeczywiście osobiście prowadził gospodarstwo rolne na płaszczyźnie przedmiotowej regulacji miała okoliczność, że bezpośrednio zarządzał tą jednostką produkcyjną i decydował o kierunku produkcji. Wspomniany Autor sformułował także tezę, iż „w dużym stopniu nieaktualny jest już pogląd, że przez gospodarowanie na nieruchomości rolnej (prowadzenie gospodarstwa rolnego) należy rozumieć w każdym wypadku nie tylko osobiste kierowanie i zarządzanie, lecz także pozostające z tym w ścisłym związku wykonywanie osobiście lub przy pomocy członków rodziny niezbędnych prac i związane z tym zamieszkiwanie w gospodarstwie rolnym", tłumacząc ją przede wszystkim zmieniającymi się warunkami społeczno-gospodarczymi. Autor zwracał uwagę przede wszystkim na coraz wyższy poziom mechanizacji prac w gospodarstwie rolnym, eliminujący konieczność wykonywanie tych prac bezpośrednio i własnoręcznie przez osobę prowadzącą takie gospodarstwo Wyżej zaprezentowany pogląd został powszechnie, choć nie jednogłośnie, zaakceptowany w polskiej literaturze dotyczącej problematyki związanej z ustawą z 26 października 1971 r. oku. Por. J.S. Piątowski, Uregulowanie własności gospodarstw rolnych i zmiany w kodeksie cywilnym, „Państwo i Prawo" 1971, nr 7-8, s. 288; J. Szachułowicz, Zakres kognicji sądu na tle ustawy z dnia 26 października 1971 r. o uregulowaniu własności gospodarstw rolnych, „Palestra” 1972, nr 1, s. 24-25; S. Rakowski, Cywilnoprawne aspekty ustawy o uregulowaniu własności gospodarstw rolnych, „Nowe Prawo” 1972, nr 11, s. 1649; E. Gniewek, Nabycie własności gruntów rolnych przez posiadaczy. Podstawowe zagadnienia ustawy o uregulowaniu własności gospodarstw rolnych, Wrocław 1978, s. 55.

24 Por. pogląd J. Pietrzykowskiego (Dziedziczenie gospodarstw rolnych, Warszawa 1965, s. 27) wyrażony odnośnie kryterium osobistego prowadzenia gospodarstwa rolnego, wykorzystanego przez ustawodawcę w ustawie z dnia 29 czerwca 1963 roku o ograniczeniu podziału gospodarstw rolnych (Dz.U. Nr 28, poz. 168), jako jedna z przesłanek podmiotowych warunkujących możliwość odziedziczenia gospodarstwa rolnego. Z drugiej jednak strony w jednym ze swych orzeczeń dotyczących tej samej regulacji Sąd Najwyższy stwierdził, że nie jest wymagane, aby prowadzący gospodarstwo rolnik miał się trudnić pracą na roli. Por. Postanowienie SN z 12 lutego 1966 r., III CR 368/65, OSNCP 1966, nr 10, poz. 177. Por. P. Blajer, Pojęcie rolnika indywidualnego..., op. cit., s. 183; A. Majewski, Problematyka kwalifikacji..., op. cit., s. 185.

26 Por. A. Majewski, Problematyka kwalifikacji..., op. cit., s. 185, który interpretuje „wszelkie” decyzje jako decyzje „podstawowe”, co jest efektem podziału decyzji podejmowanych w ramach prowadzonej działalności rolniczej na decyzje „podstawowe” i „wykonawcze”. 
i orzecznictwie, ${ }^{27} \mathrm{a}$ w praktyce nie budził on nigdy większych wątpliwości, ${ }^{28}$ to jednak należy wyrazić żal, że przy okazji najnowszej nowelizacji u.k.u.r. przegapiono okazję by skorygować redakcję przedmiotowego kryterium. Do analogicznej refleksji skłania także pozostawienie w tekście ustawy (art. 7 ust. 1) - jako dowodu potwierdzającego osobiste prowadzenie gospodarstwa rolnego - oświadczenia prowadzącego to gospodarstwo, poświadczonego przez wójta (burmistrza, prezydenta miasta), pomimo iż w praktyce ,poświadczone przez wójtów oświadczenia” przybierają postać zaświadczeń wydawanych na podstawie k.p.a. ${ }^{29}$

2.4. Najistotniejszym modyfikacjom $w$ ramach definicji rolnika indywidualnego poddane zostało kryterium kwalifikacji rolniczych. Wprowadzone zmiany eliminują wiele kontrowersji, które otaczały poprzednią redakcję tego kryterium, w związku z czym należy uznać je za w pełni racjonalne. Zdecydowano się bowiem odejść od rozwiązania, które traktowało osoby posiadające wykształcenie wyższe lub średnie, inne niż rolnicze, za posiadające wykształcenie rolnicze. Aktualnie przepis art. 6 ust. 2 pkt 2) u.k.u.r. stosunkowo precyzyjnie wskazuje co należy rozumieć pod pojęciem kwalifikacji rolniczych. ${ }^{30} \mathrm{~W}$ przeciwieństwie do poprzedniego sposobu ujmowania kwalifikacji rolniczych w u.k.u.r. nowa regulacja wprowadziła szczególnego rodzaju „konfuzję” dwóch do tej pory oddzielnie traktowanych rodzajów kwalifikacji rolniczych, tj. kwalifikacji teoretycznych i praktycznych. W konsekwencji na same tylko kwalifikacje teoretyczne może powołać się wyłącznie osoba o wykształceniu stricte rolniczym zasadniczym zawodowym, średnim lub wyższym. ${ }^{31} \mathrm{~W}$ pozostałych przypadkach konieczny jest jeszcze określony staż pracy w rolnictwie, przy czym im dana osoba posiada lepsze wykształcenie, tym ten staż pracy jest krótszy. ${ }^{32}$

27 Por. wyrok Sądu Najwyższego z dnia 29 stycznia 2008 r. IV CSK 447/07, Lex nr 37141, w którym Sąd potwierdził, iż w praktyce często zdarza się, że w ramach przyjętego w rodzinie podziału obowiązków tylko jedno z małżonków zajmuje się prowadzeniem gospodarstwa, drugie zaś np. prowadzi gospodarstwo domowe lub pracuje poza rolnictwem; nie ma jednak racjonalnych przesłanek, by gospodarstwa w ten sposób prowadzone wyłączać z kategorii rodzinnych.

28 Por. T. Ciodyk, T. Zagórski, P. Iwaszkiewicz, Ustawa o kształtowaniu ustroju rolnego w praktyce, „Studia luridica Agraria" 2005, t.4, s. 149.

29 Ibidem, s. 148.

30 Zgodnie z brzmieniem powołanego przepisu uważa się, że osoba fizyczna posiada kwalifikacje rolnicze, jeżeli uzyskała: a) wykształcenie rolnicze zasadnicze zawodowe, średnie lub wyższe lub b) tytuł kwalifikacyjny lub tytuł zawodowy, lub tytuł zawodowy mistrza w zawodzie przydatnym do prowadzenia działalności rolniczej i posiada co najmniej 3-letni staż pracy w rolnictwie, lub c) wykształcenie wyższe inne niż rolnicze i posiada co najmniej 3-letni staż pracy w rolnictwie albo wykształcenie wyższe inne niż rolnicze i ukończone studia podyplomowe w zakresie związanym z rolnictwem, albo wykształcenie średnie inne niż rolnicze i posiada co najmniej 3-letni staż pracy w rolnictwie, lub d) wykształcenie podstawowe, gimnazjalne lub zasadnicze zawodowe inne niż rolnicze i posiada co najmniej 5-letni staż pracy w rolnictwie.

31 Por. rozporządzenie Ministra Rolnictwa i Rozwoju Wsi z dnia 17 stycznia 2012 roku w sprawie kwalifikacji rolniczych posiadanych przez osoby wykonujące działalność rolniczą (Dz.U. z 2012 r. Nr 109), określające między innymi kierunki studiów wyższych, których ukończenie uznaje się za posiadanie wykształcenia wyższego rolniczego oraz zawody, których posiadanie uznaje się za wykształcenie średnie rolnicze lub wykształcenie zasadnicze zawodowe rolnicze.

32 Stosownie do nowego art. 6 ust. 3 u.k.u.r. za „staż pracy” uznaje się okres, w którym osoba fizyczna: 1) podlegała ubezpieczeniu społecznemu rolników lub 2) prowadziła działalność rolniczą w gospodarstwie rolnym o obszarze nie mniejszym niż 1 ha stanowiącym jej własność, przedmiot użytkowania wieczystego, przedmiot samoistnego posiadania lub dzierżawy, lub 3) była zatrudniona w gospodarstwie rolnym na podstawie umowy o pracę 
Nowa redakcja kryterium kwalifikacji rolniczych w u.k.u.r. zachęca do sformułowania kilku ogólniejszych spostrzeżeń. Przede wszystkim zwraca uwagę fakt, że w dalszym ciągu ustawa odwołuje się do tradycji wąskiego, ,abstrakcyjnego” ujmowania pojęcia kwalifikacji rolniczych, rozumianych jako tzw. kwalifikacje zawodowe, a więc odpowiednie wykształcenie teoretyczne lub doświadczenie w pracy w rolnictwie (staż pracy). ${ }^{33}$ Rozwiązanie to należy uznać za uzasadnione, pozwala bowiem na dokładne określenie, kiedy dana osoba posiada odpowiednie kwalifikacje. W związku z powyższym ustawa nowelizująca i wydane na jej podstawie przepisy wykonawcze przyniosły także doprecyzowanie dowodów potwierdzających fakt posiadania wymaganych kwalifikacji rolniczych. ${ }^{34}$

Na szczególne jednak uznanie zasługuje zasygnalizowane w ustawie nowelizującej dążenie do uniformizacji pojęcia „kwalifikacje rolnicze” w ramach całego polskiego systemu prawa rolnego. Nowa definicja tych kwalifikacji w u.k.u.r. stanowi bowiem dosłowne powtórzenie sposobu ich określenia na płaszczyźnie regulacji dotyczących rent strukturalnych w ramach Programu Rozwoju Obszarów Wiejskich na lata 2007-2013. ${ }^{35} \mathrm{~W}$ ten sposób ustawodawca wyszedł naprzeciw postulatom doktryny zmierzającym do zapewnienia spójności systemu prawnego poprzez ujednolicenie pojęcia „,kwalifikacji rolniczych” w ramach tych regulacji, które się do niego odwołują. ${ }^{36} \mathrm{~W}$ związku z powyższym modyfikacje wprowadzone w 2011 roku w sposobie ujmowania kryterium kwalifikacji rolniczych - pomimo licznych szczegółowych niedoskonałości ${ }^{37}$ - należy uznać za udane i wnoszące najwięcej pozytywnych zmian w zakresie całej definicji rolnika indywidualnego w u.k.u.r.

lub spółdzielczej umowy o pracę, wykonując pracę związaną z prowadzeniem działalności rolniczej, lub 4) wykonywała pracę związaną z prowadzeniem działalności rolniczej w charakterze członka spółdzielni produkcji rolnej, lub 5) odbyła staż, o którym mowa w art. 53 ust. 1 ustawy z dnia 20 kwietnia 2004 r. o promocji zatrudnienia i instytucjach rynku pracy (Dz.U. z 2008 r. Nr 69, poz. 415 z późn. zm.), obejmujący wykonywanie czynności związanych z prowadzeniem działalności rolniczej.

33 Por. P. Blajer, Wymóg kwalifikacji rolniczych..., op. cit., s. 69.

34 Por. art. 7 ust. 8 u.k.u.r. w nowym brzmieniu oraz wydane na podstawie delegacji zawartej w tym przepisie cytowane wyżej rozporządzenie Ministra Rolnictwa i Rozwoju Wsi z dnia 17 stycznia 2012 roku w sprawie kwalifikacji rolniczych posiadanych przez osoby wykonujące działalność rolniczą.

35 Por. $§ 7$ ust. 2 rozporządzenie Ministra Rolnictwa i Rozwoju Wsi z dnia 19 czerwca 2007 r.oku w sprawie szczegółowych warunków i trybu przyznawania pomocy finansowej w ramach działania „Renty strukturalne”, objętego Programem Rozwoju Obszarów Wiejskich na lata 2007-2013 (Dz.U Nr 109, poz. 750). Bardzo podobnie, choć z pewnymi modyfikacjami redakcyjnymi kwalifikacje rolnicze zdefiniowane zostały w $\S 6$ rozporządzenia Ministra Rolnictwa i Rozwoju Wsi z dnia 17 października 2007 roku w sprawie szczegółowych warunków i trybu przyznawania pomocy finansowej w ramach działania „Ułatwianie startu młodym rolnikom”, objętego Programem Rozwoju Obszarów Wiejskich na lata 2007-2013 (Dz.U. Nr 200, poz. 1443).

36 Por. P. Blajer, Koncepcja prawna..., op. cit., s. 353 i sformułowany tam postulat odwołania się do sposobu ujęcia kwalifikacji rolniczych w ramach przepisów o rentach strukturalnych, jako potencjalnego wzoru dla innych regulacji wykorzystujących to kryterium, w szczególności u.k.u.r.

37 Warto zwrócić uwagę np. na nieproporcjonalność wymogów, których spełnienie pozwala uczynić zadość przesłance stażu pracy w rolnictwie. Z jednej strony (art. 6 ust. 3 pkt 1 u.k.u.r.) wystarczy trzy- lub pięcioletnie podleganie ubezpieczeniu społecznemu rolników, a więc przesłanka stosunkowo nietrudna do spełnienia, jeśli tylko dysponuje się co najmniej jednym hektarem przeliczeniowym użytków rolnych (art. 16 ust. 1 pkt 1 ustawy z dnia 20 grudnia 1990 roku o ubezpieczeniu społecznym rolników, Dz.U. z 2008 r. Nr 50, poz. 291 ze zm.) Z drugiej natomiast strony (art. 6 ust. 3 pkt 3 u.k.u.r.) osoba zatrudniona w gospodarstwie rolnym na podstawie umowy o pracę lub spółdzielczej umowy o pracę - by powołać się na wystarczający staż pracy w rolnictwie - musi przez analogiczny okres świadczyć pracę związaną z prowadzeniem działalności rolniczej. 


\section{Zmiany w zakresie statusu rolnika indywidualnego}

O ile modyfikacje samej definicji rolnika indywidualnego w u.k.u.r. rzeczywiście mają istotne znaczenie, rzutując w poważnym stopniu na dotychczasowy sposób rozumienia tego pojęcia, o tyle tego samego nie można powiedzieć o zmianach w zakresie statusu osób spełniających wskazane ustawą kryteria, czyli osób będących rolnikami indywidualnymi.

Analiza znowelizowanych przepisów u.k.u.r. oraz u.g.n.r. prowadzi do wniosku, że uściślenie kryteriów składających się na definicję rolnika indywidualnego podyktowane było wyłącznie troską o ograniczenie kręgu potencjalnych uczestników postępowań przetargowych na sprzedaż (i dzierżawę) nieruchomości z Zasobu Własności Rolnej Skarbu Państwa, regulowanych drugą z wyżej wymienionych ustaw. Wskazuje na to treść znowelizowanego art. 29 ust. 3b u.g.n.r., zgodnie z treścią którego Agencja może między innymi zastrzec, że w przetargu mogą uczestniczyć wyłącznie rolnicy indywidualni w rozumieniu przepisów o kształtowaniu ustroju rolnego, zamierzający powiększyć gospodarstwo rodzinne, jeżeli mają oni miejsce zamieszkania w gminie, w której położona jest nieruchomość wystawiana do przetargu lub w gminie graniczącej z tą gminą, lub osoby posiadające kwalifikacje rolnicze określone w przepisach o kształtowaniu ustroju rolnego, zamierzające utworzyć gospodarstwo rodzinne w rozumieniu tych przepisów. W ten sposób, jak podniesiono w literaturze, ustawodawca dokonał unifikacji przepisów u.g.n.r. z przepisami u.k.u.r., ${ }^{38}$ ale wyłącznie w wąskim zakresie obejmującym dystrybucję państwowych gruntów rolnych pomiędzy rolników. Wniosek ten zdaje się potwierdzać lektura uzasadnienia projektu ustawy nowelizującej, w którym de facto jako jedyny powód zmiany definicji rolnika indywidualnego w u.k.u.r. wymieniono zbyt ogólne określenie kryteriów składających się na poprzednią definicję tego pojęcia. Taki stan rzeczy prowadził w konsekwencji do sytuacji, gdy w przetargach ograniczonych organizowanych przez ANR dla rolników powiększających gospodarstwa rodzinne uczestniczyły osoby spełniające formalnie ustawowe kryteria, ale niebędące w rzeczywistości związane $\mathrm{z}$ rolnictwem i nabywające nieruchomości rolne wyłącznie dla otrzymywania różnego rodzaju dopłat lub w celach spekulacyjnych. W efekcie zatem pozycja rolników indywidualnych spełniających aktualne surowsze kryteria uległa wzmocnieniu na płaszczyźnie przepisów o przetargach na sprzedaż (i dzierżawę) państwowych nieruchomości rolnych, chociażby z tego powodu, że zawężeniu uległ krąg osób upoważnionych do udziału w takich przetargach w sytuacji, gdy ANR decyduje się ograniczyć przetarg do osób wymienionych w art. 29 ust. 3 b u.g.n.r. 
Ustawa nowelizująca nie przyniosła natomiast większych zmian w zakresie statusu rolników indywidualnych na gruncie u.k.u.r., a więc podstawowego aktu określającego zasady kształtowania ustroju rolnego państwa - w tym także przez zapewnienie prowadzenia działalności rolniczej w gospodarstwach rolnych przez osoby o odpowiednich kwalifikacjach. Co więcej, można zaryzykować twierdzenie, że w ostatnich latach przeważa tendencja do osłabiania statusu rolników indywidulanych $w$ ramach instytucji przewidzianych w u.k.u.r. Tytułem przykładu można wskazać, iż wprowadzenie w 2010 roku regulacji zakładającej, że prawo pierwokupu oraz nabycia przysługujące ANR na podstawie odpowiednio art. 3 ust. 4 oraz 4 u.k.u.r. aktualizuje się dopiero w przypadku, gdy przedmiotem umowy jest nieruchomość rolna o powierzchni nie mniejszej niż 5 ha, ${ }^{39}$ pociągnęło za sobą skutek w postaci zdecydowanego spadku ilości umów ograniczonych wspomnianymi uprawnieniami ANR. W konsekwencji zmniejszyło się także praktyczne znaczenie przywileju zastrzeżonego w u.k.u.r. (art. 3 ust. 7 oraz art. 4 ust. 4 pkt 1) na rzecz rolników indywidualnych, umożliwiającego im nabywanie nieruchomości rolnych bez ingerencji ze strony ANR.

Wniosek o stopniowym osłabianiu statusu rolników indywidualnych na płaszczyźnie u.k.u.r. zdaje się również potwierdzać wprowadzenie mocą ustawy nowelizującej zupełnie nowego art. 4a u.k.u.r., zgodnie z treścią którego prawo pierwokupu dzierżawcy, o którym mowa w art. 3 ust. 1 tej ustawy - a więc uprawnienie zastrzeżone dla rolnika indywidualnego, prowadzącego na dzierżawionej nieruchomości gospodarstwo rodzinne - przysługuje wyłącznie dzierżawcy całego gospodarstwa rolnego. W doktrynie zwrócono uwagę, iż redakcja art. 4a u.k.u.r. zdaje się ostatecznie eliminować rozpowszechniony w literaturze pogląd, iż dzierżawcy nieruchomości rolnej przysługuje prawo pierwokupu także w przypadku, gdy przedmiotem sprzedaży jest gospodarstwo rolne wydzierżawiającego, a dzierżawiona nieruchomość stanowi jego część, a to z uwagi na interes społeczno-gospodarczy, przemawiający za utrzymaniem warsztatu produkcyjnego dzierżawcy ${ }^{40}$ Nowy sposób ujęcia prawa pierwokupu dzierżawcy gospodarstwa rolnego pozostawia ponadto praktyczną możliwość skorzystania z tego uprawnienia dobrej woli stron umowy sprzedaży, bowiem od tego, jak strony te określą w umowie przedmiot sprzedaży, zależy de facto faktyczny zakres uprawnień dzierżawcy. ${ }^{41}$

Ustawa nowelizująca nie przyniosła także żadnych zmian w zakresie nielicznych przywilejów przyznanych rolnikom indywidualnym na podstawie aktów

Mocą art. 1 ustawy z dnia 6 maja 2010 roku o zmianie ustawy o kształtowaniu ustroju rolnego (Dz.U. Nr 110, poz. 725), obowiązującego od 8 lipca 2010 roku.

40 Por. A. Suchoń, Z prawnej problematyki gospodarowania na dzierżawionych gruntach rolnych, „Studia luridica Agraria" 2011, t.9, s. 77-78.

41 P. Blajer, Ustawowe prawo pierwokupu gospodarstwa rolnego w świetle nowelizacji ustawy o kształtowaniu ustroju rolnego, (w:) Rozprawy z prawa cywilnego, własności intelektualnej i prawa międzynarodowego. Księga pamiątkowa dedykowana prof. Bogusławowi Gawlikowi, red. J. Pisuliński, F. Zoll, Kraków 2012. 
prawnych innych niż u.k.u.r. oraz u.g.n.r., ${ }^{42}$ ani też nie przyznała im żadnych dodatkowych praw. W związku z powyższym szczególny status tej grupy społeczno-zawodowej, pomimo deklaracji zawartych w uzasadnieniu do projektu noweli, przedstawia się w dalszym ciągu nadzwyczaj skromnie.

\section{Uwagi końcowe}

Przeprowadzone powyżej szczegółowe rozważania dotyczące najnowszych zmian w zakresie definicji rolnika indywidualnego oraz statusu osób spełniających kryteria składające się na tę definicję zachęcają do sformułowania kilku uwag o ogólniejszym charakterze. Przede wszystkim zaznaczyć należy, że wejście w życie ustawy nowelizującej w żadnym wypadku nie oznacza przełomu w dotychczasowym podejściu polskiego ustawodawcy do instytucji rolnika indywidualnego i gospodarstwa rodzinnego. W zakresie redakcji kryteriów pozwalających uznać daną osobę za rolnika indywidualnego wprowadzone modyfikacje oznaczają wyłącznie doprecyzowanie sformułowań i wyeliminowanie szczególnie rażących mankamentów poprzedniej regulacji. W tym kontekście z pewnością zasługuje na uznanie nowa redakcja kryterium kwalifikacji rolniczych. Z drugiej jednak strony niektóre usterki charakterystyczne dla poprzedniej regulacji zostały utrzymane, a ponadto nowela wprowadziła nowe sformułowania, np. w zakresie kryterium osobistego prowadzenia gospodarstwa, których interpretacja również wywołuje uzasadnione wątpliwości. Należy również podkreślić, że mocą przepisów ustawy nowelizującej nie dokonano żadnych zmian odnośnie do samego doboru kryteriów składających się na definicję rolnika indywidualnego. Rodzaj i charakter tych kryteriów pozostaje zatem jedną z najbardziej kontrowersyjnych kwestii na płaszczyźnie całej u.k.u.r. W konsekwencji liczne doktrynalne zastrzeżenia co do doboru kryteriów składających się na definicję rolnika indywidualnego oraz konkretne propozycje ulepszenia tej definicji należy uznać za nadal aktualne. ${ }^{43}$

W tym miejscu warto także nadmienić, że praktyczne znaczenie wprowadzonych ustawą z dnia 16 września 2011 roku zmian w zakresie definicji rolnika indywidualnego, także tych, które ocenić trzeba jednoznacznie pozytywnie, osłabia-

42 Por. art. 4 ustawy z dnia 9 maja 2008 roku o Agencji Restrukturyzacji i Modernizacji Rolnictwa (Dz.U. z 2008 r., $\mathrm{Nr}$ 98, poz. 634 z późn. zm.), zgodnie z treścią którego zadaniem wymienionej Agencji jest między innymi wspieranie poprawy struktury agrarnej, w tym zwłaszcza tworzenia i powiększania gospodarstw rodzinnych w rozumieniu przepisów o kształtowaniu ustroju rolnego, a zadanie to Agencja realizuje w szczególności poprzez dopłatę do odsetek od kredytów bankowych lub częściową spłatę kapitału kredytu udzielonego na zakup nieruchomości rolnych, które utworzą takie gospodarstwo lub wejdą w jego skład.

Por. w szczególności E. Kremer, Odpowiedzialność za zobowiązania związane z prowadzeniem gospodarstwa rolnego, Kraków 2004, s. 349; A. Lichorowicz, O instytucji gospodarstwa rodzinnego - de lege ferenda, "Rejent” 1996, nr 7, s. 41 i n.; idem, Status prawny gospodarstw rodzinnych w ustawodawstwie krajów Europy Zachodniej, Białystok 2000, s. 230; P. Blajer, Pojęcie rolnika indywidualnego..., op. cit., s. 196; idem, Koncepcja prawna..., op. cit., s. 347 i n. 
ją przepisy przejściowe zawarte w ustawie nowelizującej. Zgodnie bowiem z treścią art. 7 wymienionego aktu prawnego osoby fizyczne, które w dniu wejścia w życie niniejszej ustawy (3 grudnia 2011 roku) są rolnikami indywidualnymi w rozumieniu u.k.u.r. w brzmieniu dotychczasowym i nie spełniają warunków składających się na definicję rolnika indywidualnego $\mathrm{w}$ brzmieniu nadanym ustawą nowelizującą, przez okres 5 lat od dnia wejścia w życie ustawy nowelizującej, uznaje się za osoby spełniające te warunki. W konsekwencji poprzednia, pełna usterek i mankamentów redakcja kryteriów składających się na definicję rolnika indywidualnego, jeszcze do 3 grudnia 2016 roku będzie miała rozstrzygające znaczenie dla ustalenia, czy dana osoba może uzyskać status rolnika indywidualnego. Wystarczy bowiem tylko, że osoba taka wykaże, iż w dniu 3 grudnia 2011 roku spełniała warunki składające się na definicję rolnika indywidualnego w jej dotychczasowym brzmieniu.

Ocena regulacji zawartych w ustawie nowelizującej nie jest również jednoznaczna z perspektywy nowych rozwiązań dotyczących statusu rolników indywidualnych. Można odnieść wrażenie, że podstawową - jeżeli nie wyłączną - przyczyną zmian w zakresie definicji rolnika indywidualnego była konieczność uszczelnienia systemu przetargów na sprzedaż i dzierżawę państwowych nieruchomości rolnych, określonego przepisami u.g.n.r. W tym zatem zakresie nowa definicja rolnika indywidualnego będzie zapewne spełniała swoje zadanie, uprzywilejowując osoby spełniające nowe, surowsze kryteria. Niemniej na płaszczyźnie pozostałych regulacji prawnorolnych status rolników indywidualnych nie uległ żadnym zmianom, a nawet, jak wskazywano, pod pewnymi względami ich pozycja uległa osłabieniu. To spostrzeżenie prowadzi z kolei do wniosku, że po raz kolejny nie wykorzystano okazji, by instytucja rolnika indywidualnego, a w konsekwencji także gospodarstwa rodzinnego, zaczęła w końcu odgrywać istotną rolę - należną jej chociażby z racji konstytucyjnego umocowania. Potrzeba zaś stworzenia prawidłowej definicji rolnika indywidualnego, obejmującej wyspecjalizowaną grupę zawodową prowadzącą działalność rolniczą oraz zapewnienie takiej grupie odpowiedniego statusu, wydaje się aktualnie coraz bardziej oczywista, również w kontekście najnowszych tendencji w ramach ustawodawstwa rolnego Unii Europejskiej, które zdaje się aktualnie ukierunkowywać swoje regulacje - i w szczególności przewidziane nimi wsparcie - na czynnych zawodowo rolników. ${ }^{44}$ Uczynienie z rolników indywidualnych podstawo-

Por. np. art. 28 ust. 2 rozporządzenia Rady (WE) nr 73/2009 z dnia 19 stycznia 2009 roku (Dz. Urz. UE z 31 stycznia 2009 r. L. 30, s. 16-99), zgodnie z treścią którego państwa członkowskie mogą ustanowić odpowiednie i niedyskryminujące kryteria, aby zapewnić, że płatności bezpośrednie nie będą przyznawane osobom fizycznym ani prawnym, w których działalność rolnicza stanowi tylko nieznaczną część ogółu ich działalności gospodarczej lub których główna działalność gospodarcza, lub przedmiot działalności nie polegają na prowadzeniu działalności rolniczej. W konsekwencji państwa członkowskie mogą w ustawodawstwie krajowym przewidzieć regulacje, które zapewnią, że płatności bezpośrednie trafią do rolników, a zatem osób których działalność rolnicza stanowi główne źródło dochodu. Por. D. Łobos-Kotowska, Prawna konstrukcja płatności bezpośrednich po zmianach wprowadzonych w ramach przeglądu health check polityki rolnej. Miejsce przeglądu w procesie ewolucji instrumentu płatności i powody jego przeprowadzenia (w:) Ocena prawna wpływu health check na przyszłość Wspól- 
Definicja i status rolnika indywidualnego w świetle nowelizacji ustawy o kształtowaniu...

wych adresatów unijnego wsparcia mogłoby zatem przyczynić się do nadania tej instytucji należnego jej znaczenia.

nej Polityki Rolnej, red. B. Rakoczy, Toruń 2010, s. 124. Na potrzebę kierowania wsparcia finansowego wyłącznie do czynnych zawodowo rolników zwraca uwagę również Komisja Europejska w swoim komunikacie z dnia 18 listopada 2010 roku, zatytułowanym „WPR do 2020 r.: sprostać wyzwaniom przyszłości, związanym z żywnością, zasobami naturalnymi oraz aspektami terytorialnymi”, dostępnym na stronie Ministerstwa Rolnictwa i Rozwoju Wsi. 


\section{THE NOTION AND STATUS OF INDIVIDUAL FARMER ACCORDING TO THE AMENDMENTS TO THE BILL ON SHAPING OF AGRICULTURAL STRUCTURE}

Key words: individual farmer, legal definition, agricultural law.

The article discusses a wide range of issues concerning the amendments introduced to the Polish bill od 11th April 2003 on shaping of agricultural structure by the law of 16th September 2011. Among other things, the law altered definition of the individual farmer, one of the most important institutions in Polish system of agricultural law.

In the first instance, the article examines the modifications of the criteria which construct the definition of the individual farmer. Among them the special emphasis is laid on the criterion of professional qualifications, because of the fact that its redaction was strongly criticized on the basis of the former legislation. Author makes an attempt to evaluate the new formulation of above mentioned definition trying to point out its both positive and negative aspects.

Further, Author describes current status of individual farmers in Polish agricultural law, indicating few regulations which concern this professional group in Poland. The analysis refers to the situation after the introduction of the law of 16th September 2011 and results in firm dispraise of the current regulations.

With respect to above-mentioned arguments, the strong need of further studies both on definition of individual farmer and his status in Polish legal system- is to be stressed. 